\title{
Analysis of a leprosy-specific antibody epitope
}

\author{
W B BROWN, W A LARRABEE \& P S KIM \\ Whitehead Institute for Biomedical Research, Cambridge, Mass., USA
}

\section{Inttroduction}

The $65 \mathrm{kD}$ protein antigen is of immunological importance in medically relevant mycobacteria, including $M$. leprae, $M$. tuberculosis, and BCG $(1,2)$. Although the $65 \mathrm{kD}$ antigen is believed not to be a cell-surface protein $(2,3)$, patients with leprosy or tuberculosis, and BCG-vaccinated individuals, are found to have antibodies and T-cells that recognize the 65 $\mathrm{kD}$ antigen (4-8). Whether epitopes on the $65 \mathrm{kD}$ antigen are necessary or sufficient for protective immunity is unknown.

At least 6 different antibody epitopes for the $65 \mathrm{kD}$ antigen have been defined using competitive radioimmunoassays $(1,5)$. One of these epitopes (recognized by the monoclonal antibody IIIE9) is unique to $M$. leprae and the remainder are shared with the $65 \mathrm{kD}$ proteins from other mycobacteria.

Using recombinant methods, Young and co-workers have developed a method of epitope mapping that has localized a linear epitope recognized by IIIE9 to a 15 amino acid region of the $65 \mathrm{kD}$ antigen (9). A synthetic peptide containing the predicted 15 amino acid sequence was used to confirm the epitope (9). Recently, Shinnick (10) has obtained the DNA sequence of the $65 \mathrm{kD}$ antigen from $M$. tuberculosis. In the region comparable to the IIIE9 epitope there are 3 amino acid differences from the $M$. leprae sequence (10). Since IIIE9 does not recognize the $65 \mathrm{kD}$ antigen from $M$. tuberculosis, these results suggest that one or more of these 3 amino acid residues is responsible for the specificity of IIIE9.

To investigate this epitope further, we have synthesized a peptide which contains the authentic $M$. leprae epitope, a peptide which contains all three amino acid substitutions found in the $M$. tuberculosis sequence, and peptides containing each of these amino acid substitutions individually. ELISA has been used to evaluate binding of IIIE9 to these peptides.

\section{Materials and methods}

IIIE9 ascites (2) was obtained from L. Walker, Center for Disease Control, Atlanta, Georgia, U.S.A. Alkaline phosphatase conjugated goat anti-mouse IgG was obtained from Southern Biotechnology Associates. p-nitrophenyl phosphate was from Sigma. Peptide synthesis reagents were from Applied Biosystems. All other chemicals were reagent grade.

\section{PEPTIDE SYNTHESIS}

Peptides were synthesized using the solid-phase method (11) on an automated model 430A peptide synthesizer from Applied Biosystems. Amino acids were coupled as symmetric anhydrides, and acetic anhydride capping was used at the end of each coupling reaction. The efficiency of coupling was monitored using a ninhydrin assay on resin samples samples obtained at the end of each coupling reaction (12). 
Peptides were deprotected and cleaved from the resin using an HF-cleavage protocol from Dr. D. Davis, Applied Biosystems. $1 \mathrm{gm}$ of resin was cleaved in $10 \mathrm{ml}$ of HF, using $1.5 \mathrm{ml}$ anisole and $0.5 \mathrm{ml}$ dimethyl sulfide as scavengers. The cleavage was allowed to occur for $30 \mathrm{~min}$ at $-20^{\circ} \mathrm{C}$ (methanol-ice mixture) followed by $30 \mathrm{~min}$ at $0^{\circ} \mathrm{C}$. After cleavage, scavengers were extracted with ether, and peptide was extracted using $5 \%$ acetic acid.

The peptides were partially purified using C18 Sep-pak cartridges (Millipore). $5 \%$ acetic acid was used as the loading solvent and also for washing the cartridge. Peptide was eluted in $5 \%$ acetic acid containing $70 \%$ acetonitrile. This elution was diluted with an equal volume of water and lyophilized. We find that the capacity of the cartridges is typically $10-15 \mathrm{mg}$ of peptide (R. Rutkowski, unpublished).

\section{ELISA EXPERIMENTS}

Peptides were fixed to the bottom of 96-well microtiter plates using the procedure of Ninman \& Elder (13). $50 \mu \mathrm{l}$ of peptide $(0.1 \mathrm{mg} / \mathrm{ml})$ in phosphate buffered saline (PBS) was added to each well and the solution was allowed to dry by incubation overnight at $37^{\circ} \mathrm{C}$. Methanol was added for $5 \mathrm{~min}$ at $23^{\circ} \mathrm{C}$. Non-specific binding sites were blocked with $2 \%$ bovine serum albumin (BSA) in PBS, by incubating for at least 2 hours at $23^{\circ} \mathrm{C}$.

Ascites was diluted in PBS containing $0.2 \%$ BSA and $0.1 \%$ Triton X-100. The antibody dilutions were added to the microtiter wells and allowed to incubate for $1 \mathrm{hr}$ at $23^{\circ} \mathrm{C}$. After washing with PBS, alkaline phosphatase conjugated goat anti-mouse IgG antibody (1:500 dilution) was added to the wells for $1 \mathrm{hr}$ at $23^{\circ} \mathrm{C}$. After washing with PBS, p-nitrophenyl phosphate $(1 \mathrm{mg} / \mathrm{ml}$ in $10 \%$ diethanolamine, $\mathrm{pH} 9.8)$ was added to the wells. After $1 \mathrm{hr}$ at $23^{\circ} \mathrm{C}$, the absorbance in each well was determined at $410 \mathrm{~nm}$ using a microplate reader.

\section{Results}

Figure 1 gives the amino acid sequences for the peptides studied here. The peptide designated Lep-A corresponds to the epitope recognized by IIIE9, as determined by Mehra et al. (9).

$\begin{array}{cccccccccccccccc} & 1 & 2 & 3 & 4 & 5 & 6 & 7 & 8 & 9 & 10 & 11 & 12 & 13 & 14 & 15 \\ \text { LEP-A } & \text { Ala-Leu-Asp-Lys-Leu-Lys-Leu-Thr-Gly-Asp-Glu-Ala-Thr-Gly-Ala }\end{array}$

LEP-B Thr -Leu-Asp-Lys-Leu-Lys-Leu-Thr-Gly-Asp-Glu-Ala-Thr-Gly-Ala

LEP-C Ala-Leu-Asp-Gly-Leu-Lys-Leu-Thr-Gly-Asp-Glu-Ala-Thr-Gly-Ala

LEP-D Ala-Leu-Asp-Lys-Leu-Lys-Leu-Glu-Gly-Asp-Glu-Ala-Thr-Gly-Ala

TB-A Thr-Leu-Asp-Glu-Leu-Lys-Leu-Glu-Gly-Asp-Glu-Ala-Thr-Gly-Ala

Figure 1 .

Amino acid sequences of the peptides studied here. All peptides were synthesized with N-terminal cysteine residues (for coupling purposes in future experiments) which are not depicted in the figure. The sequence designated Lep-A corresponds to the epitope for IIIE9 determined by Mehra et al. (9). Lep-B, Lep-C, and Lep-D countain single amino acid substitutions from Lep-A as shown. TB-A contains all three amino acid substitutions, corresponding to the sequence for the homologous region of the $65 \mathrm{kD}$ antigen in $\mathrm{M}$. tuberculosis. 
The peptide designated TB-A corresponds to the sequence for the homologous region of the $65 \mathrm{kD}$ antigen in M. tuberculosis, as determined by Shinnick (10). The peptides designated Lep-B, Lep-C, and Lep-D contain point substitutions from the Lep-A sequence at residues 1, 4 , and 8 respectively: the amino acid substitutions correspond to those found in the $M$. tuberculosis sequence.

Figure 2 depicts binding of the monoclonal antibody IIIE9 to these different peptides, where the ELISA absorbance is plotted as a function of ascites dilution. The results (Figure 2) indicate that Lep-B binds as well or almost as well as the authentic $M$. leprae epitope in Lep-A. In contrast, the single amino acid substitutions found in Lep-C or Lep-D essentially abolish binding of the antibody to the peptide. TB-A, which contains all three amino acid substitutions, also shows no significant binding.

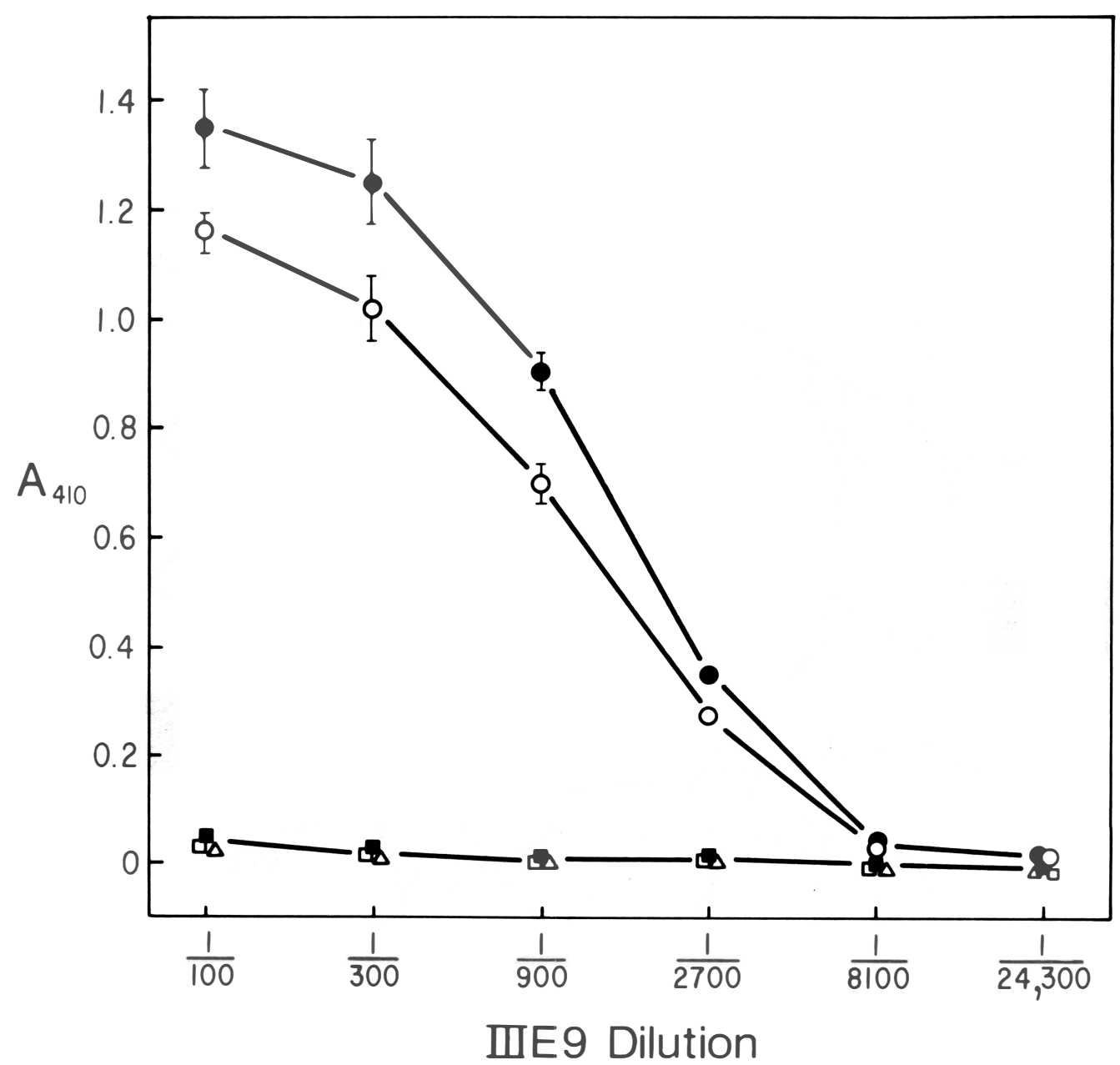

Figure 2

ELISA results for binding of IIIE9 to the peptides. The absorbance at $410 \mathrm{~nm}$ after $1 \mathrm{hr}$ of substrate incubation is plotted as a function of ascites dilution. (O) Lep-A. (O) Lep-B. Lep-C. ( $\square$ ) Lep-D. ( $\Delta$ ) TB-A. 


\section{Discussion}

The epitope recognized by the monoclonal antibody IIIE9 is the only epitope in the $65 \mathrm{kD}$ antigen that is known to be specific for $M$. leprae. Previous work localized a linear epitope recognized by IIIE9 to a 15-residue region of the $65 \mathrm{kD}$ antigen (9), and DNA sequencing of the $M$. tuberculosis homologue indicated that there were only three amino acid substitutions in this 15-residue region (10). These amino acid substitutions occur at positions 1, 4 and 8 .

Our results indicate that the amino acid substitutions at positions 4 or 8 are individually capable of eliminating binding of IIIE9 to peptides when ELISA is used. The amino acid substitution at position 1 appears to be less important.

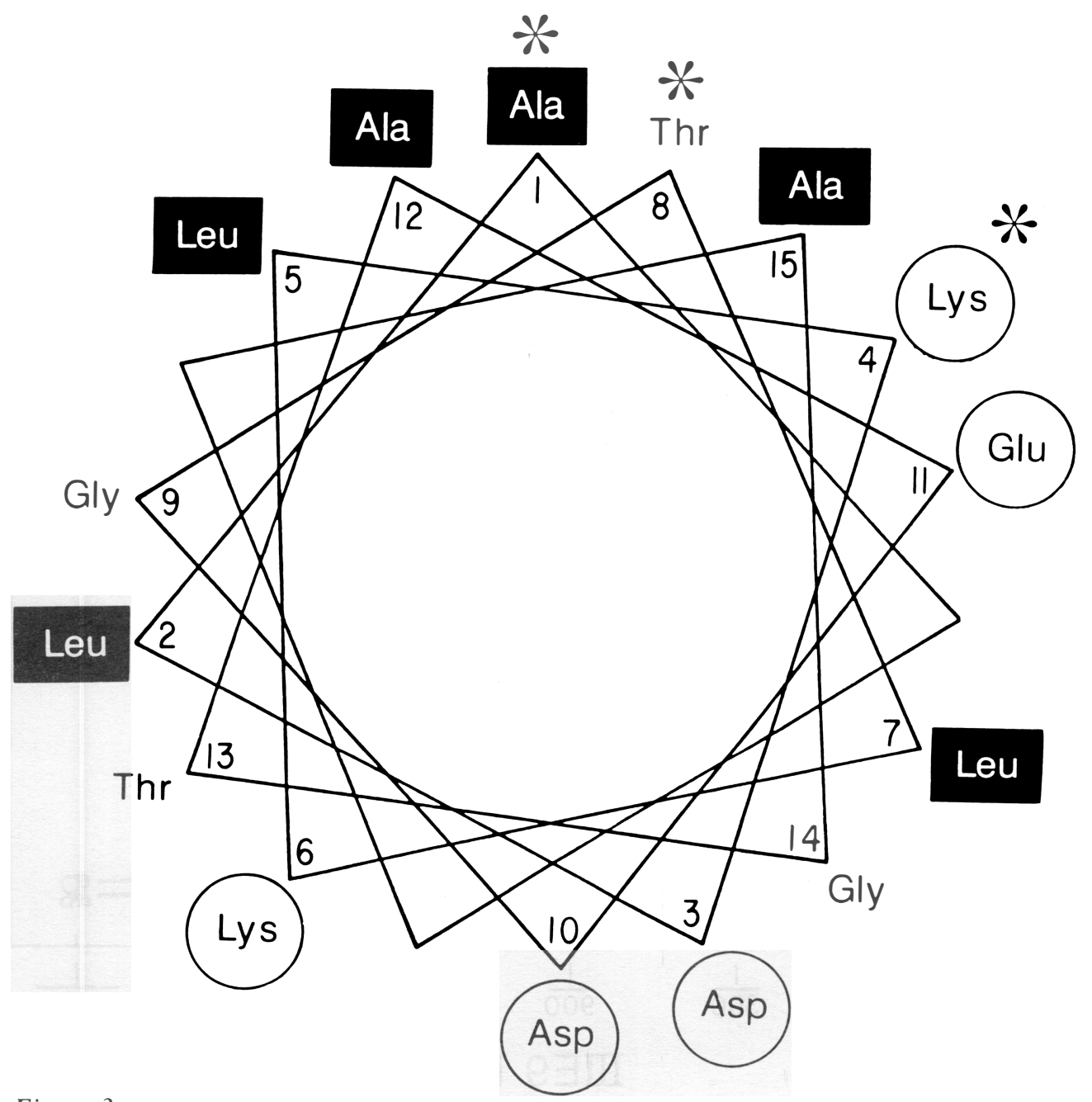

Figure 3:

Helical wheel representation (14) of the IIIE9 epitope. The helix is hypothetical: the figure is given here to indicate that if the epitope is helical then the helix is amphipathic. Residues in black boxes are hydrophobic and circled residues are charged. The asterisks refer to residues that are different in the protein from M. tuberculosis. 
The results suggest that it will be possible to localize further the linear epitope recognized by IIIE9. Our conclusions are preliminary: it is possible but unlikely that the amino acid substitutions have abolished the ability of the peptides to stick to the microtiter wells. We plan to measure binding of the peptides to the antibody in solution (e.g., using radioimmunoassays or competitive ELISA).

If the 15 residue antibody epitope studied here is also found to be a T-cell epitope, then it will be interesting to see how the amino acid changes studied here affect T-cell recognition. The helical wheel representation of Schiffer \& Edmundsom (14) indicates that this sequence is capable of forming an amphipathic $\alpha$-helix (Figure 3 ). It has been suggested that T-cell antigenic sites tend to be amphipathic helices $(15,16)$. All three amino acid substitutions found in the $M$. tuberculosis sequence are on the same face of this presumptive helix (Figure 3).

\section{Acknowledgements}

We are pleased to acknowledge numerous stimulating discussions with Drs. R. A. Young and B. R. Bloom, and to thank them for their encouragement. We also thank Dr. D. Davis and D. Sweetser for discussion. This work was supported by grants to P.S.K. from the Heiser Program for Research in Leprosy and from the Director's Initiative Fund of the UNDP/World Bank/WHO Special Programme for Research and Training in Tropical Diseases.

\section{References}

1 Gillis T P, Buchanon T M. Production and partial characterization of monoclonal antibodies to Mycobacterium leprae. Infect. Immun. 1982 37, 172-178.

2 Gillis T P, Miller R A, Young D B, Khanolkar S R, Buchanon T M. Immunochemical characterization of a protein associated with Mycobacterium leprae cell wall. Infect. Immun. 1985 49, 371-377.

3 Ivanyi J, Sinha S, Aston R, Cussel D, Keen M, Sengupta U. Definition of species specific and cross-reactive antigenic determinants of Mycobacterium leprae using monoclonal antibodies. Clin. Exp. Immunol. 1983 52, 528-536.

4 Thole J E R, Dauwerse H G, Das P K, Groothuis D G, Schould L M, van Embden J D A. Cloning of Mycobacterium bovis BCG DNA and expression of antigens in Escherichia coli. Infect. Immun. 1985 50, 800-806.

5 Engers $\mathrm{H}$ et al. Results of a World Health Organization-sponsored workshop on monoclonal antibodies to Mycobacterium leprae. Infect. Immun. 1985 48, 603-605.

6 Engers $\mathrm{H}$ et al. Results of a World Health Organization-sponsored workshop to characterize antigens recognized by mycobacteria-specific monoclonal antibodies to Mycobacterium leprae. Infect. Immun. 1982 37, 172-178.

7 Emmrich F, Thole J, Van Embden J, Kaufmann S H E. A recombinant 64 kilodalton protein of Mycobacterium bovis Bacillus Calmette-Guerin specifically stimulates human T4 clones reactive to mycobacterial antigens. J. Exp. Med. 1986 163, 1024-1029.

8 Oftung F, Mustafa A S, Husson R, Young R A, Godal T. Human T-cell clones recognize two abundant $M$. tuberculosis antigens expressed in E. coli. $1986 \mathrm{~J}$. Immunol., in press.

9 Mehra V, Sweetser D, Young R A. Efficient mapping of protein antigenic determinants. Proc. Natl. Acad. Sci. USA 1986 83, 7013-7017.

10 Shinnick T M. The 65KD antigen of Mycobacterium tuberculosis. $1986 \mathrm{~J}$. Bacteriol., in press.

11 Barany G, Merrifield R B. Solid-phase peptide synthesis. In Gross E, Meinhoffer S J eds The Peptides. Academic Press, New York. 1979 2, 1-284. 
12 Sarin V K, Kent S B H, Tam J P, Merrifield R B. Quantitative monitoring of solid-phase peptide synthesis by the ninhydrin reaction. Anal. Biochem. 1981 117, 147-157.

13 Niman H L, Elder J H. mAbs as probes of protein structure: Molecular diversity among the envelope glycoproteins (gp70s) of the murine retroviruses. In Katz D H ed, Monoclonal Antibodies and T-cell Products. CRC Press 1982 23-51.

14 Schiffer M, Edmundson A B. Use of helical wheels to represent the structures of protein and to identify segments with helical potential. Biophys. J. 1967 7, 121-135.

15 DeLisi C, Berzofsky J A. T-cell antigenic sites tend to be amphipathic structures. Proc. Natl. Acad. Sci USA 1985 82, 7048-7052.

16 Watts T H, Gariepy J, Schoolnik G K, McConnell H M. T-cell activation by peptide antigen: Effect of peptide sequence and method of antigen presentation. Proc. Natl. Acad. Sci. USA 1985 82, 5480-5484. 